\title{
Glacier expansion in southern Patagonia throughout the Antarctic
}

\section{cold reversal}

\author{
Juan L. García ${ }^{1 *}$, Michael R. Kaplan², Brenda L. Hall ${ }^{3}$, Joerg M. Schaefer², Rodrigo M. Vega4, Roseanne Schwartz², \\ and Robert Finkel ${ }^{5}$ \\ ${ }^{1}$ Instituto de Geografía, Facultad de Historia, Geografía y Ciencia Política, Pontificia Universidad Católica de Chile, Campus San \\ Joaquín, Avenida Vicuña Mackenna 4860, comuna Macul, Santiago 782-0436, Chile \\ ${ }^{2}$ Geochemistry, Lamont-Doherty Earth Observatory, Palisades, New York 10964, USA \\ ${ }^{3}$ Earth Sciences Department and Climate Change Institute, University of Maine, Orono, Maine 04469, USA \\ ${ }^{4}$ Instituto de Ciencias de la Tierra y Evolución, Universidad Austral de Chile, Campus Isla Teja, Valdivia, Chile \\ ${ }^{5}$ Earth and Planetary Science Department, University of California-Berkeley, Berkeley, California 94720, USA
}

\section{ABSTRACT}

Resolving debated climate changes in the southern middle latitudes and potential teleconnections between southern temperate and polar latitudes during the last glacial-interglacial transition is required to help understand the cause of the termination of ice ages. Outlet glaciers of the Patagonian Ice Fields are primarily sensitive to atmospheric temperature and also precipitation, thus former ice margins record the extent and timing of past climate changes. $38{ }^{10} \mathrm{Be}$ exposure ages from moraines show that outlet glaciers in Torres del Paine $\left(51^{\circ} \mathrm{S}\right.$, south Patagonia, Chile) advanced during the time of the Antarctic cold reversal (ACR; ca. 14.6$12.8 \mathrm{ka}$ ), reaching a maximum extent by $\sim 14,200 \pm 560 \mathrm{yr}$ ago. The evidence here indicates that the South Patagonian Ice Field was responding to late glacial climate change distinctly earlier than the onset of the European Younger Dryas stadial (ca. 12.9 ka). Major glacier recession and deglaciation in the Torres del Paine region occurred by 12.5 ka and thus early in the Younger Dryas. We provide direct evidence for extensive ice in Patagonia at the very start of the ACR that agrees with atmospheric and marine records from the Southern Ocean and Antarctica. Atmospheric conditions responsible for the early late glacial expansion at Torres del Paine resulted from a climate reorganization that prompted a northern migration of the south westerly wind belt to the latitude of Torres del Paine at the onset of the ACR chronozone. essential for understanding its cause, as well as the cryosphere-atmosphere-ocean links that operated during the late glacial to Holocene transition (Ackert et al., 2008).

We use ${ }^{10} \mathrm{Be}$ and ${ }^{14} \mathrm{C}$ techniques to establish a detailed reconstruction of ice fluctuations during the entire ACR in the Torres del Paine National Park $\left(51^{\circ} \mathrm{S}, 73^{\circ} \mathrm{W}\right.$; Fig. 1), southern Chile. Torres del Paine has one of the prime late glacial moraine records in the southern middle latitudes. The excellent preservation and continuity of moraines, as well as their geographical location, make them ideal to test hypotheses of late glacial climate change at the middle latitudes, $\sim 51^{\circ} \mathrm{S}$ (Figs. 1 and 2). In Torres del Paine, previous work (Marden and Clapperton, 1995) defined four distinct moraines belts

\section{INTRODUCTION}

Understanding millennial-scale climate variability that interrupted the last deglaciation $(18.0-11.5 \mathrm{ka})$ affords insight into the nature and cause of the termination of ice ages. One prominent event, the Antarctic cold reversal (ACR, ca. 14.6-12.8 ka; Lemieux-Dudon et al., 2010) in the high southern polar latitudes, was contemporaneous with the Bølling-Allerød warm period in the north and ended at the onset of the Younger Dryas stadial (ca. 12.9-11.7 ka; Blunier and Brook, 2001), but its cause remains obscure. Recent studies (Strelin et al., 2011; Putnam et al., 2010a; Kaplan et al., 2010) show evidence for a late glacial ice expansion in southern middle latitudes near the end of the ACR ca. $13.0 \mathrm{ka}$, followed by substantial glacier recession in the subsequent millennium. However, marine and ice-core evidence indicates environmental changes associated with the onset of the ACR much earlier than $13.0 \mathrm{ka}$ (EPICA Community Members, 2004 [EPICAEuropean Project for Ice Coring in Antarctica]; Blunier and Brook, 2001; Barker et al., 2009], and the nature of climate dynamics throughout the ACR around Patagonia remains unclear (Kaplan et al., 2008; Sugden et al., 2005). Thus, resolving the timing and structure of climate changes throughout this time period on land is

*E-mail: jgarciab@uc.cl.
Figure 1. Location of Torres del Paine (white box in main image) in southern South America. Solid arrows depict inferred approximate location of south westerly wind belt at present (Miller, 1976) and different key periods during last glacialinterglacial transition as inferred from sedimentological and paleoecological records of Lamy et al. (2004), Heusser (2003), Moreno et al. (1999), and Anderson et al. (2009). White dashed lines indicate approximate present positions of Polar Front (PF), Sub-Antarctic Front (SAF), and Subtropical Front (STF). TDP-Torres del Paine; CLD-Chilean Lake District; ACArchipiélago de Chiloé; HPN-Hielo Patagónico Norte; HPS-Hielo Patagónico Sur; PB-Puerto Bandera; SM-Strait of Magellan; TF-Tierra del Fuego; BC-Beagle Channel; CD-Cordillera Darwin ice cap; LGM-

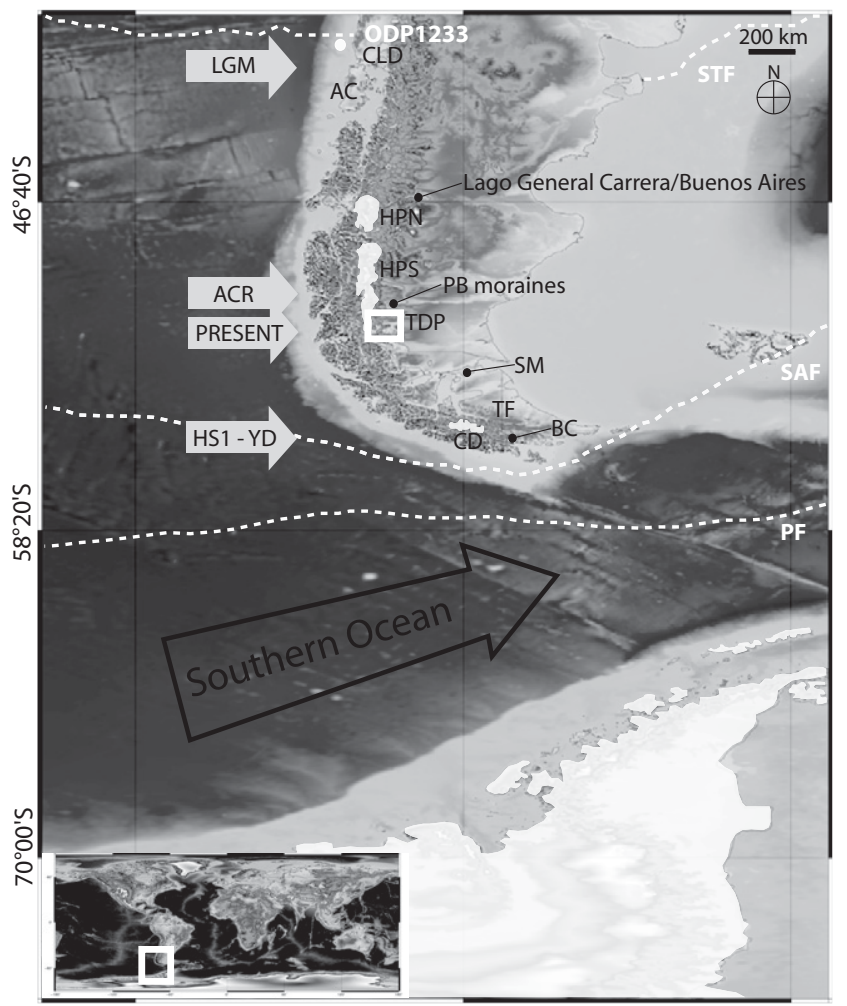

$81^{\circ} 40^{\prime} \mathrm{W}$

$70^{\circ} 00^{\prime} \mathrm{W}$ $58^{\circ} 20^{\prime} \mathrm{W}$ Younger Dryas; ODP_-Ocean Drilling Program. Base map modified from University of Maine Environmental Change Model (http://ecm.um.maine.edu). 


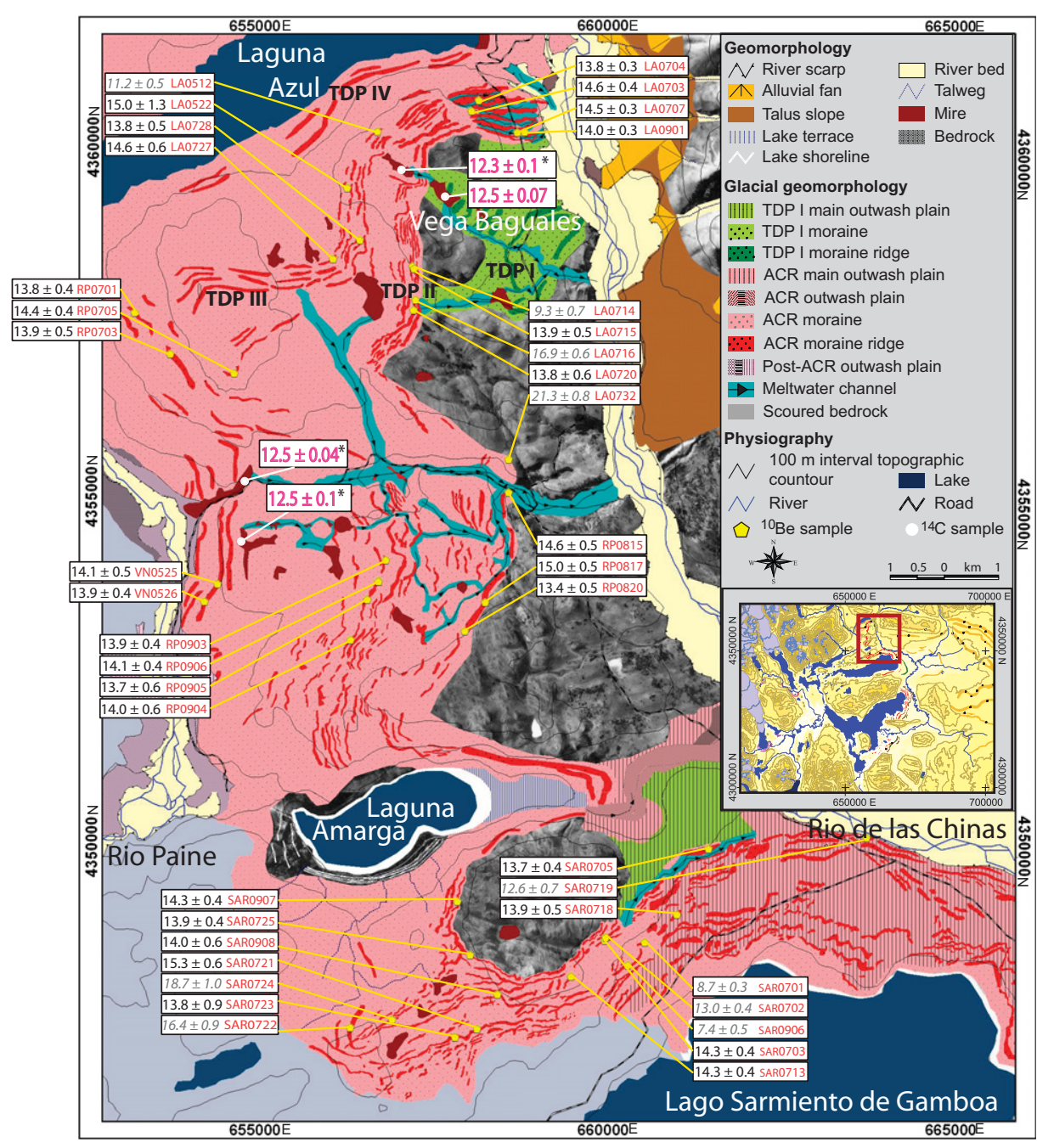

Figure 2. Glacial geomorphic map of Laguna Azul-Lago Sarmiento area in Torres del Paine National Park (inset with red box delineating extent of main map). White boxes in main map show ${ }^{10} \mathrm{Be}$ cosmogenic-exposure ages (black) and calibrated radiocarbon ages (pink; close minimum deglacial ages; asterisks represent ages from Moreno et al., 2009) in thousands of years before today and before present, respectively $( \pm 1 \sigma)$. Two ${ }^{10} \mathrm{Be}$ ages (VN0525 and VN0526) are recalculated from Moreno et al. (2009) using New Zealand ${ }^{10} \mathrm{Be}$ production rate. ${ }^{10} \mathrm{Be}$ ages in italics and gray color are statistically determined outliers. TDP-Torres del Paine; ACR-Antarctic cold reversal.

(from outer to inner, A-D) thought to have been deposited during Last Glacial Maximum (LGM) conditions. This study shows that, at present, the timing, extent, and structure of the LGM remain unknown in the Torres del Paine region. To avoid confusion with moraines of different ages having similar labels in other sites in southern South America (e.g., Sugden et al., 2005), we rename these moraines (i.e., A-D of Marden and Clapperton, 1995) here: $\mathrm{A}=$ Torres del Paine (TDP) I, B = TDP II, C = TDP III, and $\mathrm{D}=\mathrm{TDP}$ IV. These moraine sets normally occur within 2-3 km of each other, including at Laguna Azul and Lago Sarmiento (Fig. 2), and are $\geq 45 \mathrm{~km}$ from present-day ice margins. The sharp morphology of the TDP II-IV moraines contrasts with that of the TDP I moraines, which are wide, prominent landforms. TDP II, III, and IV moraines can be traced with only faces (Schaefer et al., 2009) allowing precision in our ages that averages $3.9 \%$ (1б; Fig. DR3 in the Data Repository). Our exposure ages are calculated using a ${ }^{10} \mathrm{Be}$ production rate based on a New Zealand site (Putnam et al., 2010b; see the Data Repository). This ${ }^{10} \mathrm{Be}$ production rate recently has been confirmed in the Lago Argentino area (Kaplan et al., 2011), <100 km north of Torres del Paine. We detected and rejected the outliers by applying the Grubbs (1969) test and a $2 \sigma$ criteria (see the Data Repository).

\section{RESULTS}

For each respective moraine belt, the ${ }^{10} \mathrm{Be}$ boulder ages show a normal distribution and exhibit high internal consistency after excluding outliers (Fig. DR5; see the Data Repository). Boulders from the TDP II moraines yielded ages ranging from 13.4 to $15.0 \mathrm{ka}$, with an arithmetic mean of $14.2 \pm 0.5 \mathrm{ka}(\mathrm{n}=14)$ (Fig. DR5A). The TDP III moraine boulders range from 13.7 to $15.0 \mathrm{ka}$, with a mean of 14.1 $\pm 0.5 \mathrm{ka}(\mathrm{n}=10)$ (Fig. DR5B), and those of the TDP IV moraines (including 2 ages recalculated from Moreno et al., 2009) yielded ages of $13.8-15.3 \mathrm{ka}$, with a mean of $14.1 \pm 0.7 \mathrm{ka}(\mathrm{n}=$ 6) (Fig. DR5C). The resulting ${ }^{10} \mathrm{Be}$ mean ages indicate that deposition of all three moraine systems occurred, within error, during the same time interval, and thus rapidly. The number, size, and continuity of the moraine ridges suggest that the ice was active and capable of eroding, transporting, and depositing a large volume of sediment during their formation. In the Lago Sarmiento, the TDP II moraine crosscuts the older TDP I moraine, suggesting that at least the most extensive ACR moraine in Torres del Paine represents a glacial expansion, rather than just a stillstand during retreat. In addition, near Río Paine, deformed lake beds occur in the TDP IV moraines, indicating that ice readvanced over proglacial lake deposits (Marden and Clapperton, 1995).

Maximum glacier expansion occurred by $14.2 \pm 0.5 \mathrm{ka}$ (TDP II). Local ice retreat (typically 1-3 km) occurred after TDP II moraine deposition. Then, ice readvanced and deposited the TDP III and TDP IV moraines. Despite these local glacier fluctuations, for the entire ACR time ice was still extensive $(95 \%$ of full late glacial extent) relative to the present icefield divide and outlet glacier margins. A sediment core obtained at the Vega Baguales meltwater conduit (Fig. 2) yielded a close ${ }^{14} \mathrm{C}$ minimum calibrated (cal) age of $12,460 \pm 70 \mathrm{cal}$ yr B.P. (see the Data Repository) for glacier retreat from the TDP IV moraine position in Torres del Paine. This in agreement with previous ${ }^{14} \mathrm{C}$ data from the region (Moreno et al., 2009) indicating that ice was receding at several sites in the area by $12,500 \mathrm{cal}$ yr B.P. Taken together, the ${ }^{10} \mathrm{Be}$ and ${ }^{14} \mathrm{C}$ ages indicate that ice remained at the IV position until before $12.5 \mathrm{ka}$. 


\section{DISCUSSION AND CONCLUSIONS}

This study expands and refines earlier pioneering work (Strelin et al., 2011; Sagredo et al., 2011; Moreno et al., 2009; Sugden et al., 2005; Fogwill and Kubik, 2005) that proposed the existence of expanded glaciers during the ACR period in southern South America, but lacked the extensive directly ${ }^{10} \mathrm{Be}$-dated chronological data presented here. That is, we show with direct ${ }^{10} \mathrm{Be}$ dating that glaciers in Torres del Paine were far $(\geq 45 \mathrm{~km})$ from the present-day ice at the very start of the ACR, 1300 yr before the onset of the Younger Dryas (YD). ${ }^{10} \mathrm{Be}$ and ${ }^{14} \mathrm{C}$ chronologies in Torres del Paine together afford the first terrestrial evidence for both the onset and the duration of the ACR in southern Patagonia. Collectively, with the records from glacial basins north (Strelin et al., 2011) and south (Sagredo et al., 2011) of Torres del Paine, we conclude that an unknown amount of regional glacier retreat had occurred after the LGM, before the onset of the ACR. This includes what happened immediately prior to the late glacial period.

We hypothesize that the prominent expression of the ACR at Torres de Paine could have been due to the shift of the westerly belt close to $51^{\circ} \mathrm{S}$ (Fig. 1), which would have brought not only cold conditions, but also peak precipitation to the glacial catchment. Late glacial pollen records south of $53^{\circ} \mathrm{S}$ in the southernmost tip of South America (e.g., Heusser, 2003) support such a northward shift of the westerly belt and also may imply a concurrent northward shift of the Antarctic Polar Frontal Zone, probably as far as the latitude of the Strait of Magellan (Sugden et al., 2005).

Our moraine chronology suggests that glaciers in the southern middle latitudes responded to the onset of the ACR, as recorded in Antarctic ice cores (EPICA Community Members, 2004; Blunier and Brook, 2001) (Fig. 3F). Previous work (Strelin et al., 2011; Putnam et al., 2010a; Kaplan et al., 2010) showed glaciers in the southern middle latitudes culminating at the end of the ACR chronozone. Moreover, New Zealand glaciers could have readvanced much earlier, at the start of the ACR, but data are sparse (Putnam et al., 2010a; Figs. 3A and 4). The climate signal from southern glaciers (Fig. 4; see the Data Repository) is consistent with several recently obtained ocean-atmosphere records shown in Figure 3, suggesting a coupling between oceanic, atmospheric, and cryospheric systems in the middle and high latitudes of the Southern Hemisphere. The onset of glacier readvance in south Patagonia and perhaps in New Zealand (Putnam et al., 2010a) during the early phase of the ACR (Fig. 3A) was contemporaneous with an inferred decline in the Southern Ocean upwelling rate (Anderson et al., 2009) (Fig. 3C), and likely reduced $\mathrm{CO}_{2}$ outgassing of the Southern Ocean to the atmosphere (Monnin et al., 2001)
Figure 3. Paleoclimate records discussed in text. A: ${ }^{10} \mathrm{Be}$ moraine ages from Torres del Paine (TDP) II, TDP III, and TDP IV moraines (this study, and two ${ }^{10} \mathrm{Be}$ ages from Moreno et al., 2009). See Tables DR1 and DR2 (see footnote 1). Birch Hill (BH) (Putnam et al., 2010a) and Irishman Basin (IS) (Kaplan et al., 2010) outer moraines are in New Zealand; radiocarbon-dated Puerto Bandera moraines (PB) are in Argentina (Strelin et al., 2011). B: Ocean-water temperatures as inferred from polar foraminiferal species in South Atlantic (core TNO57-21) (Barker et al., 2009). C: Southern Ocean upwelling from biogenic opal flux (Anderson et al., 2009). D: Sea-surface temperatures in southeast Pacific Ocean (Ocean Drilling Program Site 1233) inferred from Globigerina bulloides $\delta^{18} \mathrm{O}$ (Lamy et al., 2004). E: Dome C (Antarctica) atmospheric $\mathrm{CO}_{2}$ concentrations (Monnin et al., 2001) placed on Greenland Ice Sheet Project 2 (GISP2) time scale (Marchitto et al., 2007). F: Polar atmospheric mean annual temperatures derived from Byrd (Byrd Station, Antarctica) ice core $\delta^{18} \mathrm{O}$ isotopic record

(Lemieux-Dudon et al., 2010). G: Polar atmospheric mean annual temperatures derived from North Atlantic GISP2 ice core $\delta^{18} \mathrm{O}$ isotopic record (Greenland) (Stuiver and Grootes, 2000). LGM-Last Glacial Maximum; HS1-Heinrich stadial 1; ACR-Antarctic cold reversal; YDYounger Dryas.

Figure 4. Late glacial readvances at southern middle latitudes. Glacial records suggest late glacial expansions at beginning and end of Antarctic cold reversal (see the Data Repository [see footnote 1] for more details). TDPTorres del Paine II, III, and IV moraines (this study); PB-Puerto Bandera moraines at Lago Argentino, Argentina (Strelin et al., 2011); BH-Birch Hill moraines at Lake Pukaki,

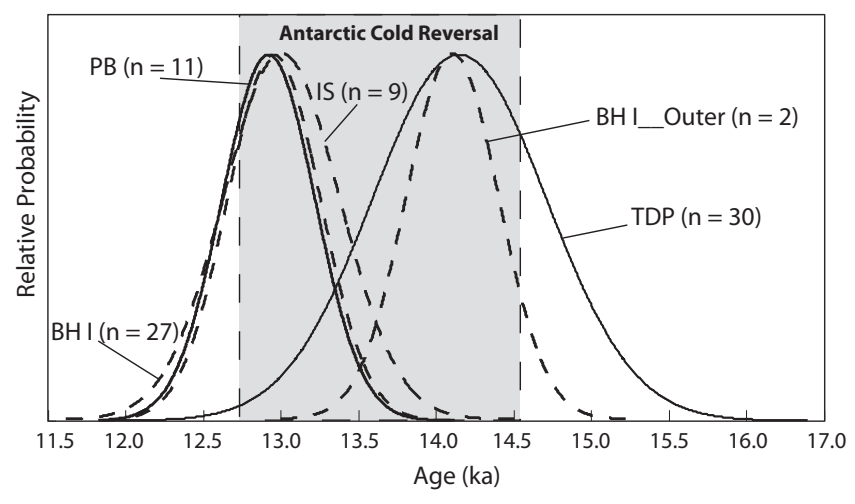

New Zealand (Putnam et al., 2010a); IS-Irishman Basin (New Zealand) outer moraines (Kaplan et al., 2010). Solid line represents Patagonian sites; dashed line represents New Zealand sites.

(Fig. 3E) at $14.6 \mathrm{ka}$. Following $\sim 1600 \mathrm{yr}$ of ACR conditions (Lemieux-Dudon et al., 2010; EPICA Community Members, 2004; Blunier and Brook, 2001), the resumed glacial to interglacial rise in the Southern Ocean upwelling and atmospheric $\mathrm{CO}_{2}$ rates after 13.0 ka coincided with rapid glacier retreat in Patagonia and New Zealand (e.g., Strelin et al., 2011; Putnam et al., 2010a; Kaplan et al., 2010; Moreno et al., 2009). 
Our study adds another important element to the scenario that significant latitudinal shifts of the westerly wind belt through termination I (Fig. 1) (Anderson et al., 2009; Denton et al., 2010) and resulting changes in Southern Ocean upwelling (Barker et al., 2009; Anderson et al., 2009; Bianchi and Gersonde, 2004; Toggweiler et al., 2006) seem to have played a prime role in the late glacial climate regime of the southern middle latitudes. Our findings support late glacial climatic links in the southern middle and high latitudes (Fig. 3) due to migrations in the Antarctic Polar Frontal Zone and westerly belt linked to Southern Ocean temperature (Bianchi and Gersonde, 2004). In addition, our data support the atmospheric bipolar seesaw model of climate change at the end of the last glaciation (Denton et al., 2010), thus suggesting that the latitudinal migration of the westerly belt throughout the termination could be tied to major oceanographic changes in the North Atlantic basin. In this scenario, throughout the ACR, the westerly belt was shifted north, bringing cold temperatures and increased precipitation to Torres del Paine, in response to a reinvigorated Atlantic meridional overturning circulation during the Northern Hemisphere Bølling-Allerød warm period.

\section{ACKNOWLEDGMENTS}

The National Geographic Society, the Churchill Exploration Fund, the Graduate Student Government at the University of Maine, and the Comer Science and Education Foundation supported this research. We are grateful to CONAF (Corporación Nacional Forestal) Región de Magallanes and Torres del Paine National Park (Chile), Víctor García, Marcelo Arévalo, Stefan Krauss, Mario Pino, and Patricio Moreno for support and assistance during field campaigns. We thank Marcelo Solari, Esteban Sagredo, Aaron Putnam, and Christopher Marden for discussions on this research. FONDECYT (Fondo Nacional de Desarrollo Científico y Tecnológico) grant 11110381 supported this publication. This is Lamont-Doherty Earth Observatory contribution 7543 .

\section{REFERENCES CITED}

Ackert, R.P., Jr., Becker, R.A., Singer, B.S., Kurz, M.D., Caffee, M.W., and Mickelson, D.M., 2008, Patagonian glacier response during the Late Glacial-Holocene transition: Science, v. 321, p. 392-395, doi: $10.1126 /$ science. 1157215 .

Anderson, R.F., Ali, S., Bradtmiller, L.I., Nielsen, S.H.H., Fleisher, M.Q., Anderson, B.E., and Burckle, L.H., 2009, Wind-driven upwelling in the Southern Ocean and the deglacial rise in atmospheric $\mathrm{CO}_{2}$ : Science, v. 323, p. 1443-1448, doi:10.1126/science.1167441.

Barker, S., Diz, P., Vautravers, M., Pike, J., Knorr, G., Hall, I.R., and Broecker, W.S., 2009, Interhemispheric Atlantic seesaw response during the last deglaciation: Nature, v. 457, p. 10971102, doi:10.1038/nature07770.

Bianchi, C., and Gersonde, R., 2004, Climate evolution at the last deglaciation: The role of the Southern Ocean: Earth and Planetary Science Letters, v. 228, p. 407-424, doi:10.1016/j.eps1 .2004.10.003.
Blunier, T., and Brook, E.J., 2001, Timing of millennial scale climate change in Antarctica and Greenland during the last glacial period: Science, v. 291, p. 109-112, doi:10.1126/science .291.5501.109.

Denton, G.H., Anderson, R.F., Toggweiler, J.R., Edwards, R.L., Schaefer, J.M., and Putnam, A.E., 2010, The Last Glacial termination: Science, v. 328, p. 1652-1656, doi: 10.1126 /science.1184119.

EPICA Community Members, 2004, Eight glacial cycles from an Antarctic ice core: Nature, v. 429 , p. 623-628, doi:10.1038/nature02599.

Fogwill, C.J., and Kubik, P.W., 2005, A glacial stage spanning the Antarctic Cold Reversal in Torres del Paine $\left(51^{\circ} \mathrm{S}\right)$, Chile, based on preliminary cosmogenic exposure dating: Geografiska Annaler, v. 87, p. 403-408, doi:10.1111/j.0435-3676 2005.00266.x.

Grubbs, F.E., 1969, Procedures for detecting outlying observations in samples: Technometrics, v. 11, p. 1-21, doi:10.2307/1266761.

Heusser, C.J., 2003, Ice age southern Andes: A chronicle of paleoecological events: Amsterdam, Netherlands, Elsevier, 240 p.

Kaplan, M.R., Moreno, P.I., and Rojas, M., 2008, Glacial dynamics in southernmost South America during Marine Isotope Stage 5e to the Younger Dryas chron: A brief review with a focus on cosmogenic nuclide measurements: Journal of Quaternary Science, v. 23, p. 649-658, doi:10.1002 /jqs. 1209.

Kaplan, M.R., Schaefer, J.M., Denton, G.H., Barrell, D.J.A., Chinn, T.J.H., Putnam, A.E., Andersen, B.G., Finkel, R.C., Schwartz, R., and Doughty, A.M., 2010, Glacier retreat in New Zealand during the Younger Dryas stadial: Nature, v. 467, p. 194-197, doi:10.1038/nature09313.

Kaplan, M.R., Strelin, J.A., Schaefer, J.M., Denton, G.H., Finkel, R.C., Schwartz, R., Putnam, A.E., Vandergoes, M.J., Goehring, B.M., and Travis, S.G., 2011, In-situ cosmogenic ${ }^{10}$ Be production rate at Lago Argentino, Patagonia: Implications for late-glacial climate chronology: Earth and Planetary Science Letters, v. 309, p. 21-32, doi:10.1016/j.eps1.2011.06.018.

Lamy, F., Kaiser, J., Ninnemann, U., Hebbeln, D., Arz, H.W., and Stoner, J., 2004, Antarctic timing of surface water changes off Chile and $\mathrm{Pa}$ tagonian Ice Sheet response: Science, v. 304, p. 1959-1962, doi:10.1126/science.1097863.

Lemieux-Dudon, B., Layo, E., Petit, J.R., Waelbroeck, C., Svensson, A., Ritz, C., Barnola, J.M., Narcisi, B.M., and Parrenin, F., 2010 Consistent dating for Antarctic and Greenland ice cores: Quaternary Science Reviews, v. 29, p. 8-20, doi:10.1016/j.quascirev.2009.11.010.

Marchitto, T.M., Lehman, S.J., Ortiz, J.D., Flückiger, J., and van Geen, A., 2007, Marine radiocarbon evidence for the mechanism of deglacial atmospheric $\mathrm{CO}_{2}$ rise: Science, v. 316, p. $1456-$ 1459, doi:10.1126/science.1138679.

Marden, C.J., and Clapperton, C.M., 1995, Fluctuations of the South Patagonian Icefield during the last glaciation and the Holocene: Journal of Quaternary Science, v. 10, p. 197-209, doi:10.1002 /jqs.3390100302.

Miller, A., 1976, The climate of Chile, in Schwerdtfeger, W., ed., World survey of climatology 12 : Climates of Central and South America: Amsterdam, Netherlands, Elsevier, p. 113-145.

Monnin, E., Indermühle, A., Dällenbach, A., Flückiger, J., Stauffer, B., Stocker, T.F., Raynaud, D., and Barnola, J.M., 2001, Atmospheric $\mathrm{CO}_{2}$ concentrations over the Last Glacial termination: Science, v. 291, p. 112-114, doi:10.1126 /science.291.5501.112.

Moreno, P.I., Lowell, T.V., Jacobson, G.L., Jr., and Denton, G.H., 1999, Abrupt vegetation and climate changes during the last glacial maximum and last termination in the Chilean Lake District: A case study from Canal de la Puntilla ( $\left.41^{\circ} \mathrm{S}\right)$ : Geografiska Annaler, v. 81 , p. $285-311$, doi:10.1111/j.0435-3676.1999.00059.x.

Moreno, P.I., Kaplan, M.R., Francois, J.P., Villa-Martinez, R., Moy, C.M., Stern, C.R., and Kubik, P.W., 2009, Renewed glacial activity during the Antarctic cold reversal and persistence of cold conditions until $11.5 \mathrm{ka}$ in southwestern Patagonia: Geology, v. 37, p. 375-378, doi:10.1130 /G25399A.1.

Putnam, A.E., Denton, G.H., Schaefer, J.M., Barrell, D.J.A., Andersen, B.G., Finkel, R.C., Schwartz, R., Doughty, A.M., Kaplan, M.R., and Schlüchter, C., 2010a, Glacier advance in southern middle-latitudes during the Antarctic Cold Reversal: Nature Geoscience, v. 3, p. 700-704, doi:10.1038/ngeo962.

Putnam, A.E., Schaefer, J.M., Vandergoes, M., Barrell, D., Kaplan, M., Goehring, B., Schwartz, R., Finkel, R., Kelley, S., and Denton, G.H., 2010b, In situ cosmogenic ${ }^{10} \mathrm{Be}$ production-rate calibration from the Southern Alps, New Zealand: Quaternary Geochronology, v. 5, p. 392409, doi:10.1016/j.quageo.2009.12.001.

Sagredo, E.A., Moreno, P.I., Villa-Martínez, R., Kaplan, M.R., Kubik, P.W., and Stern, C.R., 2011, Fluctuations of the Última Esperanza ice lobe $\left(52^{\circ} \mathrm{S}\right)$, Chilean Patagonia, during the last glacial maximum and termination 1: Geomorphology, v. 125 , p. $92-108$, doi:10.1016/j .geomorph.2010.09.007.

Schaefer, J.M., Denton, G.H., Kaplan, M., Putnam, A., Finkel, R.C., Barrell, D.J.A., Andersen, B.G., Schwartz, R., Mackintosh, A., Chinn, T., and Schluchter, C., 2009, High-frequency Holocene glacier fluctuations in New Zealand differ from the Northern Signature: Science, v. 324, p. 622-625, doi:10.1126/science.1169312.

Strelin, J.A., Denton, G.H., Vandergoes, M.J., Ninnemann, U.S., and Putnam, A.E., 2011, Radiocarbon chronologies of the late glacial Puerto Bandera moraines, southern Patagonian icefield, Argentina: Quaternary Science Reviews, v. 30, p. 25512569, doi:10.1016/j.quascirev.2011.05.004.

Stuiver, M., and Grootes, P.M., 2000, GISP2 oxygen isotope ratios: Quaternary Research, v. 53, p. 277-284, doi:10.1006/qres.2000.2127.

Sugden, D.E., Bentley, M.J., Fogwill, C.J., Hulton, N.R.J., McCulloch, R.D., and Purves, R.S., 2005, Late-glacial glacier events in southernmost South America: A blend of 'northern' and 'southern' hemispheric climatic signals?: Geografiska Annaler, v. 87, p. 273-288, doi:10.1111 /j.0435-3676.2005.00259.x.

Toggweiler, J.R., Russell, J.L., and Carson, S.R., 2006, Midlatitude westerlies, atmospheric $\mathrm{CO}_{2}$, and climate change during the ice ages: Paleoceanography, v. 21, PA2005, doi:10.1029 /2005PA001154.

Manuscript received 29 December 2011 Revised manuscript received 8 April 2012 Manuscript accepted 10 April 2012

Printed in USA 